Arq. Bras. Med. Vet. Zootec., v.64, n.3, p.721-726, 2012

\title{
Extração de DNA e avaliação da composição espécie-específica de queijos
}

\author{
[DNA extraction and evaluation of the specie-specific composition of cheeses] \\ L.V. Teixeira, C.S. Teixeira, L.G.M. Caldeira, \\ E. Bastianetto, D.A.A. Oliveira
}

Escola de Veterinária - Universidade Federal de Minas Gerais - Belo Horizonte, MG

\section{RESUMO}

Foram testados três métodos de extração de DNA em amostras de queijo, com o objetivo de identificar uma técnica eficiente para extração de DNA em amostras com várias limitações, como alto teor de gordura, alto grau de degradação do DNA e grande concentração de impurezas. A técnica que faz uso do tiocianato de guanidina mostrou-se mais adequada para identificação de adição intencional não declarada de leite bovino em queijos bubalinos, podendo ser empregada para certificação de produto específico (selo de Identidade de Espécie).

Palavras-chave: extração de DNA, queijos de búfalos, fraude, certificação

\begin{abstract}
Three methods of DNA extraction were tested in cheese samples. The objective of this study was to identify an efficient technique for DNA extraction in different samples with several limitations, such as high fat tenor, high degree of DNA degradation and great sludge concentration. The technique using Guanidine thiocyanate was more appropriate for identification of intentional undeclared addition of bovine milk in buffalo cheeses. This technique can be used for certification of a specific product (stamp of Identity of Species).
\end{abstract}

Keywords: DNA extraction, water buffalo's cheeses, fraud, certification

\section{INTRODUÇÃO}

A identificação da espécie animal na área de alimentos tem sido aplicada principalmente para detecção de fraude comercial, envolvendo substituição de matéria-prima por outras de baixo valor. É usada, também, como ferramenta para detectar material que ofereça perigo ao homem, como no caso da Bovine Spongiform Encefalopathy (BSE) Encefalopatia espongiforme bovina (Dalmasso et al., 2004; Pascoal et al., 2005; Fumière et al., 2006; Corona et al., 2007; Schönenbrücher et al., 2007; Lopparelli et al., 2007; Tanabe et al., 2007). A qualidade dos produtos alimentícios inclui a autenticidade do alimento, sendo um importante conceito para os consumidores modernos, resultando em crescente pressão nas políticas governamentais e diferentes áreas de

Recebido em 30 de novembro de 2011

Aceito em 31 de janeiro de 2012

E-mail: viana.lilian@gmail.com proteção da cadeia de produção de alimentos, por exemplo, a verificação da exatidão dos rótulos dos produtos alimentícios, por razões econômicas, religiosas ou de saúde (Branciari et al., 2000; Bottero et al., 2002; Lopez-Calleja et al., 2005; Zhang et al., 2007). Para a detecção de ingredientes animais nos alimentos e a identificação de sua origem (espécie animal), são necessárias ferramentas adequadas (Verkaar et al., 2002; Lopez-Andreo et al., 2005). Métodos baseados em DNA são amplamente aceitos por serem menos afetados pelos processos industriais, como aquecimento e fermentação (Pascoal et al., 2005; Lopparelli et al., 2007; Corona et al., 2007). O DNA mitocondrial tem bons resultados nas análises em alimentos submetidos a tratamentos com pressão e temperatura elevados, em que o DNA é parcialmente degradado (Pascoal et al., 2005; Lopparelli et al., 2007; Corona et al, 2007; Zhang et al., 2007). 
A polymerase chain reaction ( $\mathrm{PCR})$, ou reação em cadeia da polimerase, oferece a possibilidade de se detectar ingredientes animais em alimentos e de se identificar de quais espécies são originários (Partis et al., 2000; Herman, 2001; Verkaar et al., 2002; Lopez-Calleja et al., 2005). Em relação à carne, este método é eficaz tanto em matéria crua quanto em produtos fermentados, cozidos ou autoclavados (Pascoal et al., 2005; Lopparelli et al., 2007; Corona et al., 2007). Porém, em relação a produtos lácteos, a extração de DNA se torna uma etapa crítica dessa metodologia, pois este é obtido das poucas células somáticas originárias da parede do úbere presentes no leite de vacas saudáveis (Branciari et al., 2000; Herman, 2001; Rea et al., 2001; Zhang et al., 2007). O aquecimento e a manipulação do leite ou queijo também prejudicam a obtenção de fragmentos de DNA em quantidade e com qualidade (Zhang et al., 2007).

Não há no Brasil legislação que caracterize produtos de búfalo. Em relação aos queijos que também poderiam ser fabricados com leite de búfala, a legislação vigente (RIISPOA) apresenta somente os artigos 621 (muçarela), 622 e 627 (provolone), 628 (cacciocavalo), 610 (ricota), 608 (gorgonzola), em que somente o artigo 608 especifica que o queijo gorgonzola deve ser confeccionado integralmente com leite de vaca. Visando possibilitar a diferenciação de produtos feitos a partir de leite de búfala, a Associação Brasileira de Criadores de Búfalos (ABCB) instituiu o selo de pureza para tais produtos, que tem um legislação própria instituída pela Associação. Por sua vez, em relação à rotulagem de produtos de origem animal compostos, o RIISPOA (art. 801 item 2) estipula que os rótulos devem indicar sua composição qualitativa e quantitativa (inclusive em relação às espécies animais). Na Itália, país onde a produção e o consumo de produtos oriundos de búfalos é relevante, há um programa de valorização desses, com legislações que regulamentam e protegem tais produtos (Denominazione di Origine Protetta alla Carne di Bufalo Campana - Reg. 628/2008; leite e mozzarella: leis 54/97 e 107/96), que são identificados por selos.

O objetivo deste trabalho foi analisar diferentes métodos de extração de DNA a partir de queijos, bem como verificar a sensibilidade, especificidade e aplicabilidade desta técnica em rotina laboratorial, na identificação de adição não declarada de leite de vaca em queijos de búfala, como ferramenta auxiliar para a inspeção de produtos de origem animal.

\section{MATERIAL E MÉTODOS}

Foram utilizadas amostras de queijos, de marcas e tipos variados, que possuíam registro no Ministério da Agricultura, Pecuária e Abastecimento, coletados em supermercados da cidade de Belo Horizonte, durante o ano de 2008, perfazendo um total de 30 amostras, dentre as quais sete rotuladas como "puro búfalo" e 23 tradicionalmente rotuladas como produzidas a partir de leite (sem identificação da espécie proveniente). Para cada método de extração, foram utilizadas 30 repetições. Foram coletados pelos de bovinos e bubalinos, para utilização como controle positivo de amplificação.

Os dados foram analisados pelo programa SAS (SAS, 2002), como tabela de contingência $2 \times 2$, usando-se os teste de qui-quadrado $\left(\chi^{2}\right)$

Foram testadas três técnicas de extração de DNA: extração com o kit QIAMP DNA Stool mini kit (da Qiagem), conforme instruções do fabricante; pela técnica descrita por Sambrook $e t$ al.(1989); e pela técnica de Boom et al. (1990).

No método QIAMP DNA Stool mini kit, a extração foi executada conforme instruções do fabricante.

No método de Sambrook et al. (1989), o DNA da amostra de queijo foi extraído, após digestão com proteinase $\mathrm{K}$, utilizando-se as técnicas do fenol/clorofórmio/álcool-isoamílico e precipitação e purificação com etanol.

No método de Boom et al. (1990), o DNA das amostras foi extraído utilizando-se solução à base de tiocianato de guanidina e empregando-se sílica preparada com carga elétrica adequada para se prender aos fragmentos de DNA. O restante do material que não era de interesse para análise foi descartado. Posteriormente, o DNA foi separado da sílica precipitando-o por meio de etanol e acetona. 
As amostras de DNA foram quantificadas em espectrofotômetro para determinar sua concentração e qualidade (Shimadzu - UV-160), na faixa de 260 a 280nm. Após a quantificação, o DNA foi diluído em água estéril para concentração de $0,5 \mathrm{ng} / \mu \mathrm{l}$. As diluições de DNA e as soluções estoque foram armazenadas a $-20^{\circ} \mathrm{C}$, até o momento do uso.

Os controles foram feitos a partir da extração de DNA de bulbos pilosos de bovinos e bubalinos por método utilizado como rotina no laboratório. $\mathrm{O}$ protocolo usado para a extração foi fornecido pelo Laboratório de Genética Veterinária da Universidade da Califórnia-Davis (uso sob licença).

Foram empregados iniciadores universais de citocromo $b$ de artiodátilos, o que, por si só, dispensa a necessidade de controle interno para monitorar a amplificação de DNA (Partis et al., 2000), para comprovar a eficiência das técnicas e identificar possíveis fraudes. Iniciadores modificados por Verkaar et al. (2002) foram utilizados para amplificar fragmentos de DNA de 271 pares de base (pb), por meio de PCR. O sistema de amplificação da PCR foi realizado conforme protocolo adaptado de Verkaar et al. (2002), em reação contendo $5 \mathrm{mM}$ de cada iniciador, $0,2 \mathrm{mM}$ de cada dNTP, duas unidades de TaqDNApolimerase, $1 \mathrm{X}$ de tampão (à base de Tris $\mathrm{HCl} 10 \mathrm{mM} ; 15 \mathrm{mM} \mathrm{MgCl} 2.50 \mathrm{mM} \mathrm{KCl}$ ), no mínimo 10ng de DNA amostral e água Milli-Q autoclavada, perfazendo um total de $20 \mu \mathrm{L}$.

Foi feita análise de restrição de endonuclease

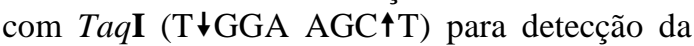
espécie bubalina e com HinfI (G\ANT C TNA G) para detecção da espécie bovina, $5 \mu \mathrm{L}$ de produto de PCR foram acrescidos de $1 \mathrm{X}$ de tampão e 5 a $10 \mathrm{U}$ de enzima de restrição (Invitrogen), submetendo-se a três horas de digestão a $65^{\circ} \mathrm{C}$ a $T a q I$ e a $37^{\circ} \mathrm{C}$ a HinfI.

Os produtos, tanto da PCR quanto dos fragmentos resultantes do corte com a enzima de restrição, foram diluídos em solução de tampão de corrida $2 \mathrm{X}$ e, então, submetidos à corrida eletroforética (200 volts, 30 miliamperes por duas horas), juntamente ao padrão de peso molecular $\left(p G E M^{\circledR}\right.$ Promega), em gel de poliacrilamida $8 \%$. Foi incluído um controle positivo para búfalo e um para bovino, extraídos de pelos, e um controle onde não é adicionado DNA, para verificar se não houve contaminação dos reagentes utilizados para a amplificação. A visualização dos produtos, tanto após PCR quanto após digestão, deu-se pela coloração dos geis com nitrato de prata.

\section{RESULTADOS E DISCUSSÃO}

A utilização da técnica com tiocianato de guanidina (Boom, 1990), bem como o uso do kit QIAMP DNA Stool para extração de DNA, apresentou diferença estatisticamente significativa pelo método do qui-quadrado $(\mathrm{P}<0,006)$ em relação à extração clássica com fenolclorofórmio (Sambrook et al., 1989). Na Tab. 1, encontra-se a porcentagem de resultados positivos e negativos conforme a utilização de cada método. Esta foi a etapa mais crítica do experimento. Teoricamente, o leite e o queijo possuem pouco teor de DNA, pois este provém das células de descamação do úbere da vaca. Além de possuir pouco DNA, o queijo ainda apresenta diversos inibidores de PCR, como alto teor de proteínas e alta degradação do DNA por microrganismos presentes nos fermentos, a partir dos quais se fazem os queijos. O método de extração de DNA por guanidina está baseado nas propriedades de ligação de partículas de sílica ao DNA na presença de tiocianato de guanidina (GuSCN), que tem ação caotrópica e de inativação de nucleases (Boom et al., 1990; Mafra et al., 2004; Corona et al., 2007). A técnica baseia-se na alteração de pH. Em condições de $\mathrm{pH}$ baixo (obtido pela adição de $\mathrm{HCl}$ ), a sílica tem carga positiva para aderir à estrutura principal de ácidos nucleicos, carregados negativamente. Proteínas e outros contaminantes não se aderem à sílica e são simplesmente eliminados com o tampão de lavagem. Para retirar os ácidos nucleicos a carga na superfície sílica é neutralizada aumentando-se o pH para 8.5, sendo usado o tampão de eluição com baixo teor de sal. O DNA purificado dilui instantaneamente no tampão e está pronto para uso em diversas aplicações. Por isso, a PCR apresentou melhores resultados após a extração de DNA pelo método que usa a guanidina. $\mathrm{O}$ método do fenol:clorofórmio apenas precipita o DNA, mantendo os demais inibidores. 
Tabela1. Resultados das metodologias de extração de DNA em queijos

\begin{tabular}{|c|c|c|c|}
\hline \multirow{2}{*}{ Técnica de extração } & \multirow{2}{*}{ N Total } & \multicolumn{2}{|c|}{ Amplificação } \\
\hline & & pPCR positivo (\%) & pPCR negativo (\%) \\
\hline Tiocianato de guanidina & 30 & 93,3 & 6,7 \\
\hline Fenol:clorofórmio & 30 & 60 & 40 \\
\hline Kit comercial & 30 & 93,3 & 6,7 \\
\hline
\end{tabular}

pPCR = produto de PCR, sem ação de enzima de restrição.

$\mathrm{n}=$ número total de amostras analisadas.

Para identificar espécies filogeneticamente próximas, como Bos taurus e Bubalus bubalis, foram usadas duas enzimas de restrição (Tab. 2), o que permitiu neutralizar o efeito de polimorfismos intraespecíficos (Partis et al., 2000; Parson et al., 2000; Verkaar et al., 2002; Bellis et al., 2003; Girish et al., 2005).

Após a digestão com enzima TaqI, o produto de PCR apresentou 108 e 163 pb para lácteos de origem bubalina, e $271 \mathrm{pb}$ para os de origem bovina, enquanto após a digestão com enzima Hinfl, os fragmentos foram de 101 e 170 pb para lácteos de origem bovina e $271 \mathrm{pb}$ para os de origem bubalina, confirmando o mencionado por Verkaar et al. (2002).

A amplificação de um fragmento relativamente pequeno de DNA (271pb) viabiliza a aplicação da técnica em produtos termicamente processados, pois o DNA quebra-se em pequenos pedaços após tratamento térmico ou degradação bacteriana (Partis et al., 2000; Pascoal et al., 2005; Arslan et al., 2006). Assim sendo, quanto menor o fragmento a ser amplificado, maiores as chances de sucesso da técnica, sendo o ideal fragmentos menores que 200pb (Arslan et al., 2006).

A escolha de fragmentos do citocromo $b$ mitocondrial para amplificação de DNA foi relevante, uma vez que este é mais abundante que o genômico, o que aumenta a sensibilidade da técnica, levando-se em consideração que as amostras de DNA são obtidas de poucas células somáticas provenientes da descamação natural do úbere de vacas saudáveis (Parson et al., 2000; Partis et al., 2000; Herman, 2001; Girish et al., 2005; Arslan et al., 2006).
A sensibilidade também se faz importante, visto que quanto mais sensível, maior a capacidade do teste para detectar pequenas porcentagens de adição de produtos de espécies diferentes (contaminação). Por isso, e também pela utilização de iniciadores espécie-específicos, nos diversos estudos já realizados sobre adulteração de queijos de búfala com leite de vaca, é possível a discriminação de adição de até $0,5 \%$ de leite de espécie diferente da declarada em queijos processados (Partis et al., 2000; Herman, 2001; Lopez-Calleja et al., 2005). Para tanto, faz-se necessária a realização da coleta de, no mínimo, três amostras (réplicas) para a análise e detecção com maior sensibilidade (Partis et al., 2000; Zhang et al., 2007). As réplicas são utilizadas quando a mensuração de uma resposta está sujeita a erros de manipulação humana, ou à variação que existe entre a medidas numa mesma amostra, justificando que o seu valor médio retrataria melhor aquela resposta para um animal (Sampaio, 2002; Zhang et al., 2007).

Como a utilização de kits comerciais gera certa dependência do laboratório com as empresas fabricantes e/ou importadoras, o uso da extração pela técnica da sílica apresenta um custobenefício altamente favorável a sua adoção na rotina laboratorial. A disponibilidade de um método analítico rápido e sensível para detecção de materiais derivados de espécies animais, proibidos ou não declarados, representa uma poderosa ferramenta para aumentar a confiabilidade da rotulagem dos produtos e o cumprimento das legislações correspondentes.

A pesquisa de mercado (Tab. 2) apresentou correspondência esperada entre o rótulo e a composição espécie-específica encontrada, exceto em uma amostra de mozzarella de búfala, 
na qual foi encontrada contaminação com leite de vaca. A atual legislação não exige a diferenciação de produtos obtidos de leite de vaca ou de búfala. No entanto, o uso do termo mozzarella já indica que o produto deve ser produzido a partir do leite de búfalas, e quando se acrescenta à especificação na identificação do produto como "de búfala", dá-se ao consumidor a falsa ideia de um derivado fabricado integralmente com o leite de búfala. Por isso, faz-se necessário o estabelecimento pelo Ministério da Agricultura Pecuária e Abastecimento de perfil de identidade e qualidade dos produtos feitos exclusivamente a partir de leite de búfala.

Tabela 2. Resultados dos testes com amostras de queijo comerciais rotulados como fabricados com leite de búfala ou de vaca

\begin{tabular}{|c|c|c|c|c|c|c|c|}
\hline \multirow{2}{*}{ Amostra } & \multirow{2}{*}{$\begin{array}{c}\frac{\mathrm{n}}{\text { Total }} \\
30\end{array}$} & \multicolumn{2}{|c|}{ Amplificação } & \multicolumn{4}{|c|}{$\begin{array}{c}\text { Cortes com enzimas para determinação } \\
\text { espécie-específica }\end{array}$} \\
\hline & & $\begin{array}{c}\text { pPCR } \\
\text { positivo }\end{array}$ & $\begin{array}{c}\mathrm{pPCR} \\
\text { negativo }\end{array}$ & $\begin{array}{c}\text { TaqI } \\
\text { positivo }\end{array}$ & $\begin{array}{c}\text { TaqI } \\
\text { negativo }\end{array}$ & $\begin{array}{c}\text { HinfI } \\
\text { positivo }\end{array}$ & $\begin{array}{c}\text { Hinf } 1 \\
\text { negativo }\end{array}$ \\
\hline Queijo de búfala & 7 & $7(23,3 \%)$ & 0 & $6(20 \%)$ & 0 & $1(3,3 \%)$ & 6 \\
\hline Queijo de vaca & 23 & $\begin{array}{c}23 \\
(76,7 \%)\end{array}$ & 0 & 0 & $23(76,7 \%)$ & $23(76,7 \%)$ & 0 \\
\hline
\end{tabular}

pPCR = produto de PCR, sem ação de enzima de restrição.

$\mathrm{n}=$ número total de amostras analisadas.

\section{CONCLUSÕES}

A técnica de PCR-RFLP tem alta especificidade e, por isso, pode ser empregada na certificação de identidade/autenticidade de produtos lácteos; enquanto a técnica PCR-RFLP detecta sequencias de DNA em amostras de derivados lácteos feitos a partir de leite pasteurizado e produtos com adição de fermentos, viabilizando sua aplicabilidade em produtos termicamente processados e queijos diversos.

\section{REFERÊNCIAS}

ARSLAN, A.; ILHAK, O.I.; CALICIOGLU, M. Effect of method of cooking on identification of heat processed beef using polymerase chain reaction (PCR) technique. Meat Sci., v.72, p.326330, 2006.

BELLIS, C.; ASHTON, K.J.; FRENEY, L. et al. molecular genetic approach for forensic animal species identification. Forensic Sci. Int., v.134, p.99-103, 2003.

BOOM, R.; SOL, C.J.; SALIMANS, M.M. et al. Rapid and simple method for purification of nucleic acids. J. Clin. Microbiol., v.28, p.495503, 1990
BOTTERO, M.T.; CIVERA, T.; ANASTASIO, A. et al. Identification of cow's milk in "buffalo" cheese by duplex polymerase chain reaction. $J$. Food Prot., v.65, p.362-366, 2002.

BRANCIARI, R.; NIJMAN, I.J.; PLAS, M.E. et al. Species origin of milk in italian mozzarella and greek feta cheese. J. Food Prot., v.63, p.362366, 2000.

CORONA, B.; LLEONARD, R.; CARPIO, Y. et al. Short communication. PCR detection of DNA of bovine, ovine-caprine and porcine origin in feed as part of a bovine spongiform encephalopathy control program. Spanish $J$. Agric. Res., v.5, p.312-317, 2007.

DALMASSO, A.; FONTANELLA, E.; PIATTI, $\mathrm{P}$. et al. A multiplex PCR assay for the identification of animal species in feedstuffs. Mol. Cell Probes, v.18, p.81-87, 2004.

FUMIÈRE, O.; DUBOIS, M.; BAETEN, V. et al. Effective PCR detection of animal species in highly processed animal by products and compound feeds. Anal. Bioanal. Chem., v.385, p.1045-1054, 2006.

GIRISH, P.S.; ANJANEYULU, A.S.R.; VISWAS, K.N. et al. Meat species identification by polymerase chain reaction-restriction fragment length polymorphism (PCR-RFLP) of mitochondrial 12S rRNA gene. Meat Sci., v.70, p.107-112, 2005. 
GOULI, Z.; MINGGUANG, Z.; ZHIJIANG, Z. et al. Establishment and application of a polymerase chain reaction for the identification of beef. Meat Sci., v.51, p.233-236, 1999.

HERMAN, L. Idetermination of the animal origin of raw food by species-specific PCR. $J$. Dairy Res., v.68, p.429-439, 2001.

LOPEZ-ANDREO, M.; LUGO, L.; GARRIDOPERTIERRA, A. et al. Identification and quantification of species in complex DNA mixtures by real-time polymerase chain reaction. Anal. Biochem., v.339, p.73-82, 2005.

LOPÉZ-CALLEJA, I.; ALONSO, G.; FAJARDO, V. et al. PCR detection of cow's milk in water buffalo milk and mozzarella cheese. Int. Dairy J., v.15, p.1122-1129, 2005.

LOPPARELLI, R.M., CARDAZZO, B., BALZAN, S. et al. Real-time TaqMan polymerase chain reaction detection and quantification of cow DNA in pure water buffalo Mozzarella cheese: method validation and its application on commercial samples. J. Agric. Food Chem., v.55, p.3429-3434, 2007.

MAFRA, I.; FERREIRA, I.M.P.L.V.O.; FARIA, M.A.; OLIVEIRA, B.P.P. A novel approach to the quantification of bovine Milk in ovine cheeses using a duplex polymerase chain reaction method. J. Agric. Food Chem., v.52, p.4943-4947, 2004.

PARSON, W.; PEGORARO, K.; NIEDERSLATTER, H.; FOGER, M. Species identification by means of the cytochromo b gene. Int. J. Legal Med., v.114, p.23-28, 2000.

PARTIS, L.; CROAN, S.; GUO, Z. et al. Evaluation of a DNA fingerprinting method for determining the species origin of meats. Meat Sci., v.54, p.369-376, 2000.

PASCOAL, A.; PRADO, M.; CALO, P. et al. Detection of bovine DNA in raw and heatprocessed foodstuffs, commercial foods and specific risk materials by a novel specific polymerase chain reaction method. Eur. Food Res. Technol., v.220, p.444-450, 2005.
REA, S.; CHIKUNI, K.; BRANCIARI, R. et al. Use of duplex polymerase chain reaction (duplex-PCR) technique to identify bovine and water buffalo milk used in making mozzarella cheese. J. Dairy Res., v.68, p.689-698, 2001.

SAMBROOK, J.; FRITSCH, E.F.; MANIATIS, T. Molecular cloning: a laboratory manual. 2.ed. Cold Spring Harbor, 1989.

SAMPAIO, I.B.M. Estatística aplicada à experimentação animal. 2.ed. - Belo Horizonte: Fundação de Estudo e Pesquisa em Medicina Veterinária, 2002. 265p.

STATISTICAL Analysis System. SAS/STAT user's guide. Version 8.0. Cary, 2002. 5v.

SCHÖNENBRÜCHER, H.; ABDULMAWJOOD, A.; GÖBEL, K.A.; BÜLTE, M. Detection of central nervous system tissues in meat products: Validation and standardization of a real-time PCR-based detection system. Vet. Microbiol., v.123, p.336-345, 2007.

TANABE, S.; MIYAUCHI, E.; MUNESHIGE, A. et al. PCR method of detection pork in foods for verifying allergen labeling and for identifying hidden pork ingredients in processed foods. Biosc. Biotechnol. Biochem., v.71, p.1663-1667, 2007.

VERKAAR, E.L.C.; NIJMAN, I.J.; BOUTAGA, K.; LENSTRA, J.A. Differentiation of cattle species in beef by PCR-RFLP of mitochondrial and satellite DNA. Meat Sci., v.60, p.365-369, 2002.

ZHANG, C.L., FOWLER, M.R.; SCOTT, N.W. et al. A taqMan real-time PCR system for the identification and quantification of bovine DNA in meats, milks and cheeses. Food Control., v.18. p.1149-1158, 2007. 